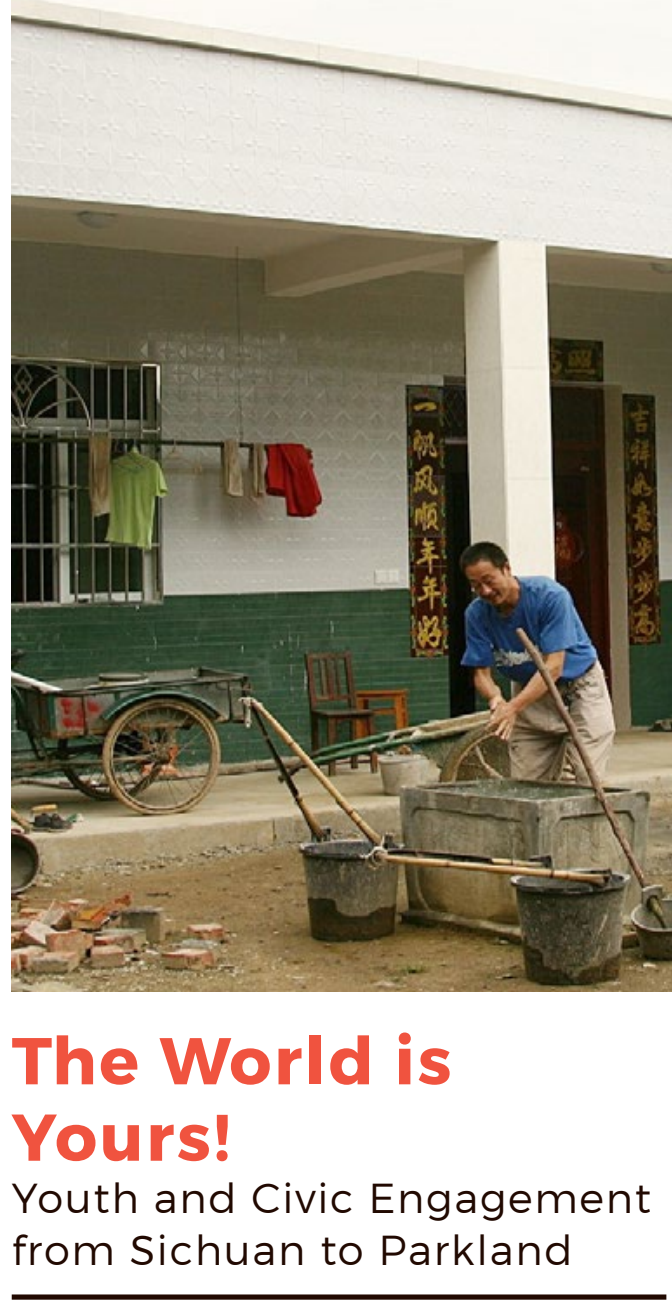

\title{
Bin XU
}

In the wake of the 2008 Wenchuan earthquake, millions of volunteers were driven by sorrow, love, and compassion to travel to Sichuan to help with the relief effort. This spontaneous and selforganised movement of idealistic youths was unprecedented in contemporary Chinese history. However, many of them failed to transcend the boundary between simple volunteering and the type of activism necessary to address the causes of suffering in the wake of the earthquake. f I had to select only one place to tell the stories of the 2008 Sichuan earthquake, I would choose Beichuan High School.

At 2:28 pm, 12 May 2008, Beichuan High was torn apart by a 7.9-magnitude earthquake. The main building collapsed and buried most of the students. Parents rushed to the school, calling their children's names and hoping they could rescue them by digging through the rubble with their bare hands and simple tools before 
heavy-duty machinery arrived. Most of their efforts, however, proved to be in vain. More than 1,000 students, roughly 30 to 50 percent of the total school population, died.

Beichuan High was one of the first places that Premier Wen Jiabao visited in the wake of the quake. Against the background of ruins, he quickly established his image as a 'grandpa' by tearfully comforting the parents and promising an all-out rescue effort. Wen visited the school eight times. During a visit to the school's temporary campus, Wen wrote down a phrase on a blackboard, 'Adversities reinvigorate a nation!' (duonan xinbang), which became one of the official catchphrases about the earthquake.

About the same time as that visit from Wen Jiabao, Siyi, a young volunteer from Guangdong, was cleaning Beichuan High's dorm building, which fortunately remained standing. During her task, she came across a piece of paper containing a handwritten love letter. Siyi could not remember the exact words or whether it was from a boy or a girl. 'But we've gone through that age, and I wasn't so much older than them,' said Siyi, 'so I felt this love letter was very special and then took a picture.' Did the student who wrote or received the letter survive? She did not know. The message, like most adolescent love letters, probably ended up nowhere, leaving nothing but a scar on a young heart. But it was found in a place where life was even more fragile than a piece of paper and evaporated as easily as a morning dewdrop. Siyi said the love letter was one of the things that compelled her to stay in the quake zone for several months, in difficult conditions-sleeping in tents and with no running water.

Siyi was one of millions of volunteers driven by sorrow, love, and compassion to go to Sichuan to help the rescue and relief effort. They are the main characters of my book The Politics of Compassion: The Sichuan Earthquake and Civic Engagement in China (2017). They cried in front of computers and televisions and decided to do something. They organised themselves into groups and travelled from places as far away as Beijing and Shanghai.
Numerous tearful eyes watched this huge wave of grassroots volunteering with surprise and delight, and many joined them. The volunteers, most of whom were young, wore t-shirts with enthusiastic slogans, cleaned toilets in crowded shelters, delivered food and water to hard-toreach areas, and taught in tent schools.

This wave of volunteering was even more extraordinary and significant when it was placed in the context of the history of the People's Republic. Youth and altruism were two things prized by the Communist leaders of yore (Gold 1991). The youths, who were not contaminated by the 'old society' before 1949, were expected to build a brand new, communist world. Mao made a famous speech to praise the youth:

The world is yours, as well as ours, but it is eventually yours. You young people, full of vigour, are blossoming, like the sun at eight or nine in the morning. Our hope is placed on you.

Note that this 'morning sun' speech was delivered to a crowd of selected elite youths, who were 'red' and smart enough to study in the Soviet Union in the 1950s. Thus, the 'you' in 'the world is yours' referred to a privileged social class represented by this particular audience. This nuance was rarely noticed, however. Communist altruism was largely embodied by Lei Feng, a young model soldier who represented not only selflessness but also loyalty to the Party. Even at the end of the Mao years, when many became disillusioned with the empty political rhetoric, a sizable army of volunteers were still mobilised by the government and their work units (danwei) to work in the devastated Tangshan area after the massive earthquake in 1976.

Nevertheless, the Sichuan earthquake was the first time so many volunteers spontaneously self-organised or were organised by civic associations, rather than by the state or their danwei. At the time, these young volunteers shattered the bias toward them-'a generation of little emperors' (xiaohuangdi). They seemed 
to instantiate China's promising future. In that moment and place, Wen's words made sense: the adversities did seem to reinvigorate a generation.

\section{Under the Night Sky, the Stars}

Siyi said that the most memorable thing about working in the quake zone was the sight of stars twinkling over the rubble, illuminating the dark Sichuan night sky. She told me: 'That's something you'll never see in cities. They're so beautiful.' This somewhat deceptive simplicity and beauty made many volunteers wish to stay in the quake zone forever. It was deceptive, because during their brief stay the volunteers could temporarily leave behind all the challenges in their day-to-day life. All human relations were reduced to the 'helper-helped' connection, and, probably more importantly, the volunteer assumed the role of a helper imbued with a somewhat condescending feeling of being needed and loved. Thus, it did not come as a surprise that the volunteers, consciously or unconsciously, attempted to be cocooned in the nice, warm comfort zone of volunteering.

Outside the comfort zone, however, the wounds of the quake were left open and raw. Many volunteers had the experience of teaching in a tent school. Not far from their tent was a pile of ruins, which the volunteers passed on a daily basis. This pile of ruins might entomb 100 or 200 students. Altogether 5,335 students died in their schools, according to official statistics. 'It was because of the earthquake!' explained the official media. But few volunteers really believed this narrative, given that many of them saw rebars in the ruins as thin as chopsticks, concrete mixed with large amounts of sand, and sometimes no rebars or concrete at all. They also heard stories of, and even saw first hand, how the students' bodies were dug out of the rubble, dead and rotten. They felt the unspeakable trauma of the parents. All these experiences would have naturally led many volunteers to a simple question: 'Why did so many schools collapse?'

Nevertheless, very few volunteers asked the question. The interviews recorded in my book show an ethical and political dilemma they faced. They wondered: 'I volunteered because I wanted to reduce the people's suffering, but should I cross the boundary to address the causes of their suffering, through serious and open public deliberations, and even activism to find out causes of the suffering?'

Those who answered yes joined the campaigns launched by $\mathrm{Ai}$ Weiwei and Tan Zuoren to collect and verify the names of student victims. They were harassed, pursued, threatened, expelled, and detained. Tan Zuoren was sentenced to five years in prison.

Those who answered no felt a sense of guilt that kept gnawing at their conscience. It was one thing to make angry comments online as a distant netizen; it was quite another if one as a volunteer actually went there, talked with the embittered survivors, and had to directly face this dilemma. Volunteers used all kinds of rhetorical devices to get around the difficult questions they faced on a daily basis-telling themselves: 'It's normal in this society'; or 'I can't change anything, and so I'll forget about it'; or simply 'I don't care'. Their apathy was not a result of an actual threat from the authorities, but a fear of imminent danger implied in the political context. That was what most Sichuan volunteers chose to do.

Even grimmer is the scenario of a 'spiral of silence': the more repressive the political context is, the less likely one is going to talk about or act on the issue of injustice; the less one talks about or acts on the issue, the more repressive the context becomes. In the end, with no hope to take action, one somehow loses the ability and desire to talk about the issue and silently buries it in the quiet realm of unconsciousness. 


\section{Reshaping Memory}

This collective silence led to the state's unchecked representation of the past-or official forgetting of some parts of this past. Official commemorations were held, and memorials were built to celebrate the 'victory of the battle against the earthquake'. The largest memorial was built right on Beichuan High's old campus. The memorial has two main buildings and many grassy mounds. The burgundy colour of the buildings fits well with the green of the mounds. Nice and clean. But, too clean. Most ruins were wiped out, but the ruins of the main classroom building which buried more than 1,000 students were too big to be removed. Instead, they are covered by a huge grassy mound with only an inconspicuous banner to tell visitors that the students and teachers of Beichuan High died there. No details. No numbers. No names. No explanations. It is also located in a place far from the normal shuttle route, so many visitors may not bother to walk that far. This strategy is what I call the 'topography of forgetting'-the state reshapes the topography of a disaster site to reshape memory.

Driven by sorrow, compassion, and the 'cando' spirit, the Sichuan volunteers accomplished something extraordinary. They transcended their group boundaries and particular interests to participate in one of the biggest waves of collective action in recent decades. But many of them failed to transcend the boundary between the 'nice, warm, and harmless' volunteering, and the activism that aims to address the causes of the suffering of the people they helped. The ultimate reason for this failure is the repressive political system, which is generally successful in subduing challenges to its legitimacy. But the political dynamics in China are complex. The system and the people constitute and reinforce each other; the boundary between the two is always blurred and porous. Not everyone can become Tan Zuoren. But everyone's superficial compassion, silence, and inaction perpetuate the unspeakable suffering of the victims, whom everyone claims to help.
I am not putting myself on a moral high ground in relation to the volunteers. I was one of them. I faced the same dilemma they did, but in a different way. I went to Sichuan first as a volunteer, then to collect data for my dissertation. The emotional toll of this research was certainly heavy. As a father, I often felt my heart was bleeding when listening to stories and seeing the ruins. Yet, I used their suffering as the 'data' to write my dissertation, to get my degree, and later to publish a book with a university press, hoping to use the book to convince the tenure committee to allow me to keep my job. I did little to reduce their misery, except for a brief period of volunteering and some donations. In all these years, I have repeatedly asked myself: am I exploiting their suffering? How can I-an academic who wrote some rarely cited articles and an Englishlanguage book which may only sell several hundred copies-address the causes of their suffering socially and politically? Honestly, I have no definitive answers.

The only thing I can do (and did) was to use my privilege as an academic writer to let people know what had happened and what my take on the issue was. I gave lectures in the United States and China, within and outside academia. In a public lecture in China, someone in the audience even brought up the tragedy of the Great Leap Forward famine-his relatives starved to death and women in his village were married to better-off outsiders to keep their current husbands and children alive-and this person was a village Party secretary! China never stops surprising an observer. So far, no National Security agent has bothered to invite me for a tea or chase me around. So, instigating these kinds of public conversations is the type of small action I am able to do now. Am I doing enough? Probably not. Am I doing the right thing? Perhaps yes. But how many of my fellow Sichuan volunteers are able to do even these small things, especially as they would have little to gain but a lot to lose if they do? Very few. 


\section{From Sichuan to Parkland}

When I was writing this essay, a generation of American youths, who are now growing up in the shadow of Donald Trump, had to face their own tragedy and an existential challenge on a bloody Valentine's Day. On 14 February 2018, a man with a semi-automatic gun killed 17 students in Marjory Stoneman Douglas High in Parkland, Florida. My sorrow was intensified by a coincidental geographic adjacency in my past. We once lived in Miami for a few years, and my daughter's violin teacher resided in a neighbourhood close to Parkland. I quickly found the similarities between Sichuan and Parkland: children died in their schools; there were 'thoughts and prayers'; the incident provoked a storm. I even cynically expected the same subsequent trajectory: after a heated debate, nothing substantive would be done, and, like Sichuan, Parkland would be forgotten or, at best, become an empty signifier like 'Columbine'.

Nevertheless, the event took a decisive turn. The youths in Stoneman Douglas High stood up for themselves. They self-organised into groups but gave a collective middle finger to the superficial 'thoughts and prayers', or to adults' lies about the 'mental illness' of the killer, or to stories about 'good guys with guns defending children from bad guys with guns'. They eloquently told the politicians who took money from the National Rifle Association a clear 'Shame on you!' They walked out of their schools. They drove to Tallahassee to pressure the Florida state legislators on gun control laws. When the petition failed at the state level, they organised a nationwide March for Our Lives, on 24 March in Washington, D.C., and almost all major cities in the United States. Parents stood with them, drove them to protests, and helped them, but it was the students, who were of the same age as those victims in Beichuan High, who occupied the front stage.
I observed this whirlwind and joined the March with sorrow, admiration, and enthusiasm. In my head cycled The Last Gunshot, a song by my favourite singer Cui Jian, which, according to speculation, may be a roundabout commemoration of the Tiananmen Square movement in 1989. The lyrics fit well with my hope:

\section{A stray bullet hit my chest. \\ All of a sudden, the past flooded my heart. \\ Oh, the last gunshot! \\ Oh, the last gunshot!}

The students in Tiananmen Square fell and never stood up again. The students in Parkland fell, but their classmates stood up and rode the wave. It would be naïve to explain their bravery only by their individual characters. Rather, it is a bravery enabled by the current political context, which, despite its defects and hypocrisy, still contains law-regulated space for open defiance. This space is much smaller and, in some situations, unthinkable in China. The Parkland students could go to the state capitol to press legislators without being threatened or detained, while the volunteers connected to Tan Zuoren and Ai Weiwei were detained and harassed without explanation. The Parkland students could organise a nationwide march, while Sichuan volunteers did not even have the desire to talk about the issue, since it was impossible for them to change anything. The public sphere also protected this space for the Parkland students' political engagement. In a CNN 'town hall', Senator Marco Rubio was grilled by the teenagers and their parents. In Sichuan, some protesting parents were repeatedly detained and placed under surveillance, and the media were muted. Even if the efforts fail, as television host Stephen Colbert said in his programme on the Parkland shooting, the youths still have a last resort: 'This is an election year. If you want to see change, you have to go to the polls to tell the people who will not protect you that their time is up' (Russonello 2018). For the Sichuan volunteers, the last resort was no resort at all. 


\section{A Candle in the Wind}

My reader, before you laugh at my naiveté, allow me to say that I am fully aware of the struggles and hardships the youth encounter in the United States and of the complexity of American politics. History is replete with American examples of slaughtered and silenced youth, such as the Kent State shooting and the killing of the Freedom Summer volunteers. I taught these events for years. But this cannot overshadow the difference between the two political systems and corresponding personal choices. Although no one would guarantee the success of the Parkland youths, they can at least do something. We adults hear their angry voices, and many of us express our own anger by joining them. In contrast, in the ten years since the Sichuan earthquake, any such attempt by the Chinese youth has been suppressed easily. All we hear is a deathly silence underpinning the state's loud self-congratulations on its successful response to the disaster.

If I sound pessimistic about Sichuan and China, let me end with a more upbeat quote from Lu Xun, who cherished hope for Chinese youths despite his deep disappointment with them.

\footnotetext{
I hope that Chinese youths will walk out of the cold air. Simply walk upward. Don't listen to the cynics. If you can do something, do something. If you can say something, say something. If you have heat, then give out light. Even if you are a firefly, you can shine in the darkness. You don't have to wait for a torch. If there is no torch in the end, then you are the only light.

Lu Xun. Hot Wind. No. 41 (author's translation)
}

Almost a century later, we still cannot say if Lu Xun's hope has any chance of becoming reality, but let us carry it like a candle in the wind. The world may be absurd enough for us to give up, but it is nevertheless our choice to continue pursuing meaning in a meaningless world. Perhaps, in the end, the Great Helmsman had a point, even anachronistically: 'The world is ours, as well as yours, but it is eventually yours!' 
This text is taken from Dog Days: A Year of Chinese Labour, Civil Society, and Rights, Made in China Yearbook 2018, edited by Ivan Franceschini and Nicholas Loubere, published 2019 by ANU Press, The Australian National University, Canberra, Australia.

doi.org/10.22459/MIC.04.2019.32 